\title{
Bernard F. Morrey, Matthew C. Morrey (eds.): Master Techniques in Orthopaedic Surgery: Relevant Surgical Exposures (Master Techniques in Orthopaedic Surgery)
}

\author{
Lippincott Williams \& Wilkins, a Wolters Kluver Company, Philadelphia, Baltimore, \\ New York, London, Buenos Aires, Hong Kong, Sydney, Tokyo: Dec 2007, 416 Pages, \\ 1200 Illustrations Hardcover, 229,00 US\$, ISBN-13: 978-0-7817-9891-4, \\ ISBN-10: 0-7817-9891-4
}

\author{
Pierre Kehr \\ Received: 28 February 2010 / Accepted: 1 March 2010 / Published online: 15 March 2010 \\ (C) Springer-Verlag 2010
}

The series "Master Techniques in Orthopaedic" was born 15 years ago, as a trial to publish top-level guidelines for experienced surgeons as well as those in training. The main author of this volume, Bernard Morrey, is one of the top leading orthopaedic surgeons, specially known for his work on elbow surgery. The list of contributors contains some well-known specialists such as Robert L. Barack for hip surgery, Douglas W. Jackson and Paul A. Lotke for knee surgery.

This book is a comprehensive review of the major surgical exposures, classified according to the anatomical location, including spine surgery. The text is easy to read, the descriptions and explanations will satisfy both experienced surgeons, who are looking for information about an uncommon procedure, and younger colleagues who want to prepare intensively for a new task. The text is well illustrated with numerous gross pictures and drawings that are clearly explained and annotated.

Besides the conventional book, the authors offer the possibility to get access to an interactive website. This allows to browse the entire content of the book online, and to download all of the images.

This book might become the top reference for all orthopaedic exposures.

Jean-Yves Jenny

Strasbourg (France)

No funds were received in support of this study.

P. Kehr $(\bowtie)$

SOTEST, Strasbourg, France

e-mail: kehrpier@aol.com 